\title{
First Record of Trichoderma asperellum
}

in Egypt

N.M. Abou-Zeid and Noher A. Mahmoud

Biological Resources Centre Standard (BRCS), Plant

Pathol. Res. Instit. ARC, Egypt.

\begin{abstract}
A $\mathbf{n}$ isolate of Trichoderma sp. was isolated during 2003 growing $\mathbf{A}_{\text {season from soil samples collected from the rhizosphere of faba }}$ bean plants grown at Fayoum Governorate, Egypt.

Identification was firstly realised by morphological criteria as Trichoderma hamatum (Bon.) Bain. Confirmation was obtained with the Biolog system that identified the strain also as T. hamatum. In addition, molecular phylogenetic method was conducted by Diaggene in the laboratory of Molecular Biotechnology of the University of Angers (France) to the strain, which referenced as Nagi I-4311 in Pasture Institute, Paris, France.
\end{abstract}

After DNA extraction with Qiagen D Neasy mini kit, three markers were used for characterization, i.e. ribosomal DNA, a fragment of the acting gene and part of the gene encoding the protein to the elongation factor (EF1). These 3 markers were amplified by PCR and sequenced in both directions by Eurofins MWG Operan (France). Sequences obtained from the 3 markers were compared by blast to the Gene Bank Database. Comparison showed that the 3 sequences of the markers, i.e. ITS $(1+2)$, EF1 and Act, showed $100 \%$ identity with the sequences of strain Trichoderma asperellum "published in Gene Bank".

Phylogenetic analysis allowed to construct a phylogenetic tree, where strain Nagi I-4311 is positioned with the strain of T. asperellum published in Gene Bank for the 3 markers used. The demonstrated strain Nagi I-4311was found to be belonged to T. hamatum. 


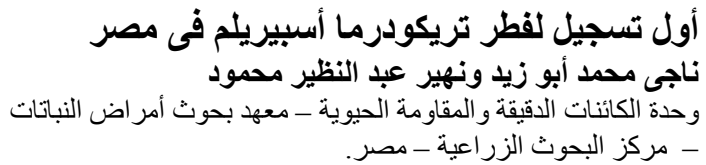

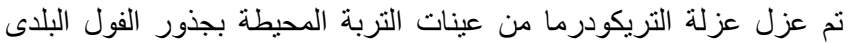

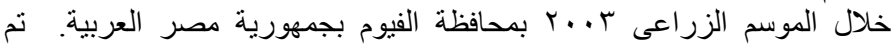

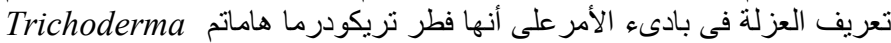
hamatum

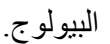

وباللجوء لتأكيد التعريف بإستخدام طرق البيولوجيا الجزيئية للأنواع المختلفة

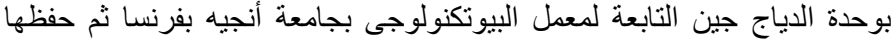
بينك الجينات بإسم Nagi I-4311 بمعهد باستير - باريس- فرنسا.

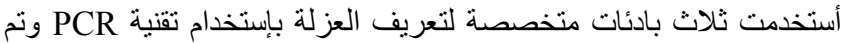

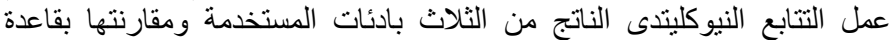

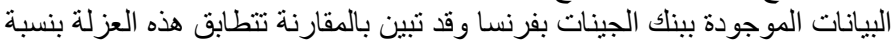

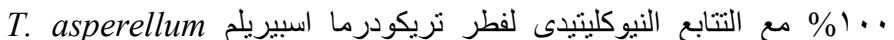

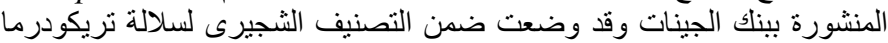
اسبيريلم وتأكد قر ابتها العالية للسلالة تريكودرما اسبيريلم. 